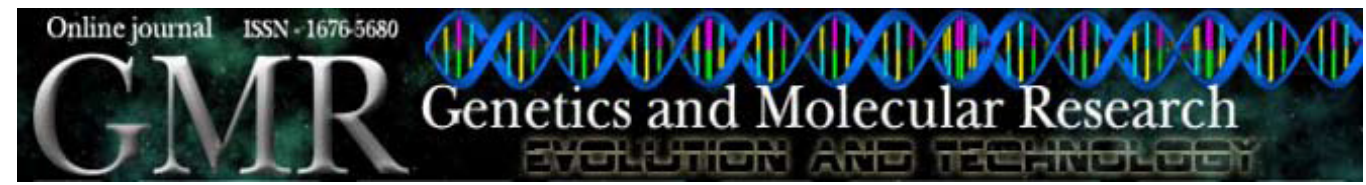

\title{
Unusual chromosome numbers in Paspalum L. (Poaceae: Paniceae) from Brazil
}

\author{
A.P.S. Peñaloza ${ }^{1}$, A.L. Côrtes ${ }^{2}$, M.T. Pozzobonn ${ }^{1}$, S. Santos ${ }^{1}$, \\ G.H. Rua ${ }^{2,3}$ and J.F.M. Valls ${ }^{1}$ \\ ${ }^{1}$ Embrapa Recursos Genéticos e Biotecnologia, Brasília, DF, Brasil \\ ${ }^{2}$ Centro Universitário de Brasília, Brasília, DF, Brasil \\ ${ }^{3}$ Facultad de Agronomía, Universidad de Buenos Aires, \\ Consejo Nacional de Investigaciones Científicas y Técnicas (CONICET), \\ Argentina \\ Corresponding author: A.P.S. Peñaloza \\ E-mail: andrea@cenargen.embrapa.br
}

Genet. Mol. Res. 7 (2): 399-406 (2008)

Received January 17, 2008

Accepted February 25, 2008

Published April 29, 2008

\begin{abstract}
Somatic chromosome numbers were determined for 20 new germplasm accessions of Paspalum, belonging to 17 species collected in Brazil. Chromosome number is reported for the first time for $P$. reduncum $(2 \mathrm{n}=18), P$. cinerascens $(2 \mathrm{n}=20), P$. cordatum $(2 \mathrm{n}=$ 20), P. filgueirasii $(2 \mathrm{n}=24), P$. ammodes $(2 \mathrm{n}=36), P$. bicilium $(2 \mathrm{n}=40)$, $P$. heterotrichon $(2 \mathrm{n}=40)$, and $P$. burmanii $(2 \mathrm{n}=48)$. New cytotypes were confirmed for two germplasm accessions of $P$. carinatum $(2 \mathrm{n}=$ $30)$ and $P$. trachycoleon $(2 \mathrm{n}=36)$, one of $P$. clavuliferum $(2 \mathrm{n}=40)$ and one of $P$. lanciflorum $(2 \mathrm{n}=40)$, indicating variability in these species. The remaining chromosome numbers reported here confirm previous counts. The unexpected chromosome numbers $2 \mathrm{n}=18$, 24, 36, and 48 in Paspalum species, which are usually shown to be multiples of 10 , suggest that much more collection and cytogenetic characterization are necessary to assess the whole chromosomal and genomic multiplicity present in the genus, which seems to be much more diverse than currently thought to be.
\end{abstract}

Key words: Cytogenetics; Cytotaxonomy; Polyploidy; Morphology 


\section{INTRODUCTION}

With about 330 species (Zuloaga and Morrone, 2005), Paspalum is one of the richest genera of Poaceae. Species of Paspalum are largely responsible for the biodiversity of grassland ecosystems in South America, and several of them are valuable forage grasses (Bennett, 1962; Allem and Valls, 1987; Filgueiras, 1992). According to Bennett and Bashaw (1966), "every desirable characteristic of a forage plant can be found in some Paspalum species". A copious literature on the cytogenetics of Paspalum and its relationship to ploidy levels, reproductive systems, natural hybridization, genomic associations, and anatomical adaptations has accumulated during the last decades (Burson, 1983; Espinoza and Quarín, 1997, 1998; Pozzobon and Valls, 2000; Daurelio et al., 2004; Machado et al., 2005; and references therein), regarding especially some polyploid hybrid complexes that include highly valuable forage species, as in the case of $P$. dilatatum Poir. Unfortunately, collections and data on genetics and reproduction from non-foraging species are far scarcer. Nevertheless, a comprehensive understanding of the genus as a whole and of the evolutionary relationships among their species requires new collections with an emphasis on underrepresented groups and particularly on the diploid species on which the several complexes are based.

With very few exceptions, base chromosome number of Paspalum species is known to be $\mathrm{x}=10$, which is a general feature of the entire clade to which Paspalum belongs (Giussani et al., 2001). The reproductive system of Paspalum is generally complex. Many Paspalum 'species' consist of sexual-diploid and apomictic-polyploid cytotypes, and several of them arose through hybridization (Quarín and Norrmann, 1990). Ploidy levels reported include 2x, 3x, 4x, $5 \mathrm{x}, 6 \mathrm{x}, 7 \mathrm{x}, 8 \mathrm{x}, 10 \mathrm{x}$, and $12 \mathrm{x}$, and species consisting only of sexual-diploid cytotypes are relatively uncommon. Apparently, sexual-diploids are distributed in rather restricted areas, as well as certain hybrid combinations (Quarín and Lombardo, 1986; Urbani et al., 2002; Daurelio et al., 2004). Moreover, groups previously thought of as rather simple autopolyploid assemblages have turned out to be complex interspecific hybrid groups (Vaio et al., 2005). Therefore, a thorough cytogenetic characterization of each new material is necessary, prior to including it in a breeding program.

In the last few years, new collections have been carried out in southern South America, which considerably expanded the number of known diploid species and/or cytotypes (Hojsgaard et al., 2005; Pozzobon et al., 2008). New chromosome counts reported in this paper, mainly corresponding to materials from Central Brazil, show several unusual chromosome numbers, not previously reported for the genus.

\section{MATERIAL AND METHODS}

All the accessions analyzed are part of the germplasm collection of Paspalum at EMBRAPA (Empresa Brasileira de Pesquisa Agropecuária), Brasília, DF, Brazil. The collections were made by Gabriel H. Rua (GHR) in several locations in the Brazilian States of Espírito Santo, Bahia, Distrito Federal, Goiás, Minas Gerais, Paraná, and Tocantins (Table 1). Vouchers were deposited at CEN and BAA.

Somatic chromosome numbers were determined in root-tip cells, following the protocols of Pozzobon and Valls (1997), with minor modifications. At least five cells with good chromosome spreading and no overlapping were analyzed per plant. Semi-permanent slides were examined using a light microscope and recorded by photomicrography. 


\section{RESULTS}

The chromosome numbers for 20 new germplasm accessions of Paspalum, belonging to 17 species, are listed in Table 1.

Table 1. Paspalum species and accessions analyzed, with somatic chromosome numbers and geographic origin.

\begin{tabular}{|c|c|c|c|c|}
\hline Species & Accession & Origin & Latitude (S) & Longitude (W) \\
\hline \multicolumn{5}{|l|}{$2 n=18$} \\
\hline \multirow[t]{2}{*}{ P. reduncum* } & GHR 816 & DF, Parque Nacional de Brasília & $15^{\circ} 43^{\prime} 59^{\prime}$, & $47^{\circ} 56^{\prime} 12^{\prime}$ \\
\hline & GHR 822 & DF, Parque Nacional de Brasília & $15^{\circ} 43^{\prime} 59^{\prime \prime}$ & $47^{\circ} 56^{\prime} 12^{\prime}$ \\
\hline \multicolumn{5}{|l|}{$2 \mathrm{n}=20$} \\
\hline P. approximatum & GHR 667 & TO, Mateiros & $10^{\circ} 22^{\prime} 29^{\prime}$, & $46^{\circ} 36^{\prime} 28^{\prime \prime}$ \\
\hline P. cinerascens* & GHR 724 & DF, Parque Nacional de Brasília & $15^{\circ} 48^{\prime} 05^{\prime \prime}$ & $47^{\circ} 47^{\prime} 20^{\prime \prime}$ \\
\hline P. cordatum* & GHR 750 & PR, Balsa Nova & $25^{\circ} 26^{\prime} 31^{\prime \prime}$ & $49^{\circ} 44^{\prime} 50^{\prime \prime}$ \\
\hline P. pumilum & GHR 716 & ES, Conceição da Barra & $18^{\circ} 35^{\prime} 17^{\prime \prime}$ & $39^{\circ} 44^{\prime} 08^{\prime \prime}$ \\
\hline \multicolumn{5}{|l|}{$2 n=24$} \\
\hline P. filgueirasii* & GHR 619 & GO, Alto Paraíso & $14^{\circ} 09^{\prime} 39^{\prime \prime}$ & $47^{\circ} 46^{\prime} 14^{\prime \prime}$ \\
\hline \multicolumn{5}{|l|}{$2 n=30$} \\
\hline P. carinatum $* *$ & GHR 773 & BA, Formosa do Rio Preto & $10^{\circ} 43^{\prime} 36^{\prime \prime}$ & $46^{\circ} 12^{\prime} 48^{\prime \prime}$ \\
\hline \multicolumn{5}{|l|}{$2 n=36$} \\
\hline \multirow[t]{2}{*}{ P. ammodes* } & GHR 693 & TO, Mateiros & $10^{\circ} 21^{\prime} 16^{\prime \prime}$ & $46^{\circ} 36^{\prime} 56^{\prime}$ \\
\hline & GHR 694 & TO, Mateiros & $10^{\circ} 21^{\prime} 16^{\prime \prime}$ & $46^{\circ} 36^{\prime} 56^{\prime}$ \\
\hline \multirow[t]{2}{*}{ P. trachycoleon** } & GHR 621 & GO, Alto Paraíso & $14^{\circ} 09^{\prime} 39^{\prime}$, & $47^{\circ} 46^{\prime} 14^{\prime \prime}$ \\
\hline & GHR 634 & GO, Niquelândia & $14^{\circ} 20^{\prime} 22^{\prime \prime}$ & $48^{\circ} 25^{\prime} 44^{\prime \prime}$ \\
\hline \multicolumn{5}{|l|}{$2 n=40$} \\
\hline P. bicilium* & GHR 645 & DF, RA IV & $15^{\circ} 34^{\prime} 39^{\prime \prime}$ & $48^{\circ} 02^{\prime} 52^{\prime \prime}$ \\
\hline P. clavuliferum $* *$ & GHR 817 & DF, Parque Nacional de Brasília & $15^{\circ} 44^{\prime} 07^{\prime \prime}$ & $47^{\circ} 55^{\prime} 37^{\prime \prime}$ \\
\hline P. conjugatum & GHR 623 & GO, Alto Paraíso & $14^{\circ} 09^{\prime} 39^{\prime \prime}$ & $47^{\circ} 46^{\prime} 14^{\prime \prime}$ \\
\hline P. heterotrichon* & GHR 644 & GO, Alto Paraíso & $14^{\circ} 09^{\prime} 39^{\prime \prime}$ & $47^{\circ} 46^{\prime} 14^{\prime \prime}$ \\
\hline P. lanciflorum** & GHR 814 & DF, Parque Nacional de Brasília & $15^{\circ} 44^{\prime} 07^{\prime \prime}$ & $47^{\circ} 55^{\prime} 37^{\prime \prime}$ \\
\hline P. millegrana & GHR 713 & ES, Guarapari & $20^{\circ} 38^{\prime} 57^{\prime \prime}$ & $40^{\circ} 28^{\prime} 44^{\prime \prime}$ \\
\hline P. nutans & GHR 721 & MG, Diamantina & $18^{\circ} 14^{\prime} 21^{\prime \prime}$ & $43^{\circ} 36^{\prime} 20^{\prime \prime}$ \\
\hline \multicolumn{5}{|l|}{$2 \mathrm{n}=48$} \\
\hline P. burmanii* & GHR 635 & GO, Niquelândia & $14^{\circ} 20^{\prime} 36^{\prime \prime}$ & $48^{\circ} 25^{\prime} 50^{\prime \prime}$ \\
\hline
\end{tabular}

*First chromosome number reported for the species.

**New chromosome number reported for the species.

From the 17 species studied, 12 showed chromosome number multiples of 10, as typical among Paspalum species. They include four diploids $(2 \mathrm{n}=20)$, one triploid $(2 \mathrm{n}=30)$, and seven tetraploids $(2 n=40)$. The remaining five accessions were surprising, because of their unusual chromosome numbers: $2 \mathrm{n}=18,24,36$, and 48 .

Chromosome numbers are reported for the first time for the following species: $P$. reduncum Ness $(2 \mathrm{n}=18)$, P. cinerascens (Döll) A.G. Burman and C.N. Bastos $(2 \mathrm{n}=20)$, P. cordatum Hack. $(2 \mathrm{n}=20)$, P. filgueirasii Morrone and Zuloaga $(2 \mathrm{n}=24)$, P. ammodes Trin. $(2 \mathrm{n}=$ 36), P. bicilium Mez $(2 \mathrm{n}=40)$, P. heterotrichon Trin. $(2 \mathrm{n}=40)$, and $P$. burmanii Filg., Morrone and Zuloaga $(2 \mathrm{n}=48)$. The chromosome numbers $2 \mathrm{n}=30$ for $P$. carinatum Humb. and Bonpl. ex Flüggé, $2 \mathrm{n}=36$ for $P$. trachycoleon Steud., and $2 \mathrm{n}=40$ for $P$. clavuliferum Wright and $P$. lanciflorum Trin. had not yet been reported for these species (see Figure 1). 

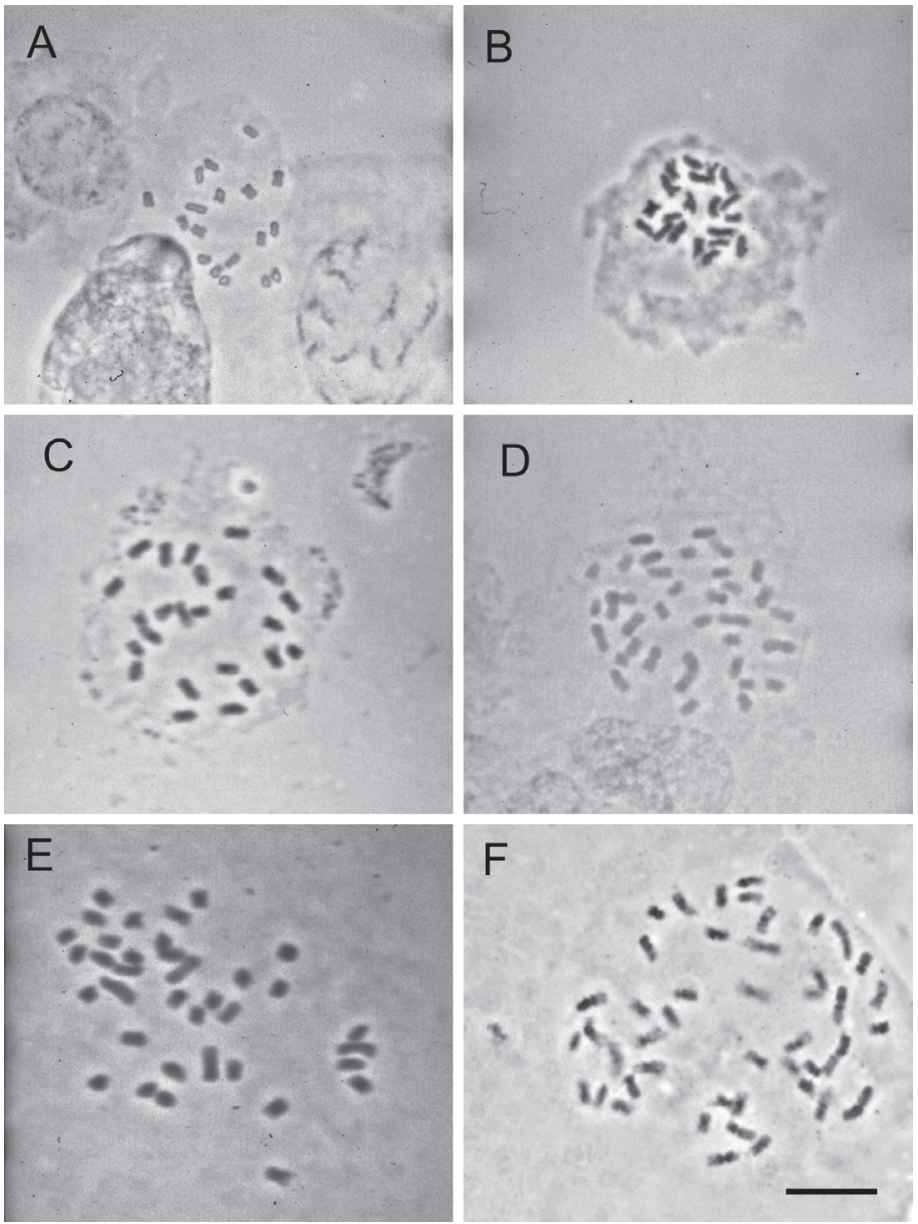

Figure 1. Mitotic metaphasic chromosomes in species of the genus Paspalum. A. P. reduncum GHR $822(2 \mathrm{n}=18)$. B. $P$. cordatum GHR $750(2 \mathrm{n}=20)$. C. P. filguerasii GHR $619(2 \mathrm{n}=24)$. D. . a ammodes GHR $693(2 \mathrm{n}=36)$. E. . trachycoleon GHR $621(2 \mathrm{n}=36)$. F. P. burmanii GHR $635(2 \mathrm{n}=48)$. Bar $=10.0 \mu \mathrm{m}$.

Chromosome counts for P. approximatum Döll and P. pumilum Nees $(2 \mathrm{n}=20)$, P. conjugatum P.J. Bergius, $P$. millegrana Schrad. and $P$. nutans Lam. $(2 \mathrm{n}=40)$ confirmed previous counts for the respective species.

\section{DISCUSSION}

Base chromosome numbers other than $\mathrm{x}=10$ have been considered exceptional in Paspalum. The few disparate cases reported in the current literature from a broad area of distribution are a count of $\mathrm{n}=9$ for P. lanciflorum (Davidse and Pohl, 1974, sub nom. P. contractum Pilg.) and two counts of $2 \mathrm{n}=32$ for $P$. convexum Humb. and Bonpl. ex Flüggé (Selva, 1976; Reeder, 1984), as well as several counts of $2 n=32$ (Honfi et al., 1990; Killeen, 1990; 
Pozzobon et al., 2000), and one of $2 \mathrm{n}=52$ for $P$. stellatum Humb. and Bonpl. ex Flüggé (Honfi et al., 1990), and the repeatedly confirmed counts of $2 \mathrm{n}=12$ and $2 \mathrm{n}=24$ for $P$. almum Chase (Quarín, 1974; Quarín and Hanna, 1980; Dandin and Chennaveeraiah, 1983; Pozzobon and Valls, 1987; Norrmann et al., 1994; Hunziker et al., 1998; Pozzobon et al., 2008). For that reason, the discovery of several accessions of Paspalum having unusual chromosome numbers in a relatively small collection from a more limited geographical area is highly surprising, and reinforces the need of intensifying collection and characterization of new materials.

Paspalum reduncum is a member of the informal group Gardneriana (Renvoize, 1972), from which previous chromosome counts are not available. The two accessions reported here, both from the National Park of Brasília (Brasília, DF, Brazil), showed $2 n=18$, suggesting a diploid level with a base chromosome number of $\mathrm{x}=9$, a condition only shared with an accession of P. $\operatorname{contractum~}(=$ P. lanciflorum) reported by Davidse and Pohl (1974), as mentioned above.

Paspalum cinerascens $(2 \mathrm{n}=20)$ and $P$. nutans $(2 \mathrm{n}=40)$ belong to the subgenus Harpostachys (Trin.) S. Denham (Denham, 2005), a group scarcely studied from a cytogenetic point of view (Acuña et al., 2005).

Paspalum filgueirasii $(2 \mathrm{n}=24)$ is a little-known species, endemic to the Brazilian Central Plateau (Morrone and Zuloaga, 2003), probably related to P. ellipticum Döll and to the Venezuelan P. atabapense Davidse and Zuloaga. Chromosome numbers reported for $P$. ellipticum are $2 \mathrm{n}=40$ (Morrone et al., 2006) and $2 \mathrm{n}=80$ (Fernandes et al., 1974). Chromosome number multiples of 6, as reported for $P$. almum (see above) are very rare among Panicoid grasses. Since no data on meiotic behavior are currently available for P. filgueirasii, the base chromosome number $\mathrm{x}=6$ for this species is conjectural.

Paspalum ammodes $(2 \mathrm{n}=36)$ is a species currently ascribed to the informal group Eriantha (Morrone et al., 2004), which seems to be a largely polyphyletic assemblage (Speranza P and Rua GH, unpublished results). The unusual chromosome number of both accessions studied points to a base chromosome number of either $\mathrm{x}=6$ or $\mathrm{x}=9$. Both accessions differ in the pigmentation of the anthers. Whereas anthers of GHR 693 are purple, as typical for this species, those of GHR 694 are yellow. Interestingly, anther pigmentation is associated with ploidy level and mode of reproduction, with a few exceptions in P. dilatatum Poir. (Burson, 1983; Pozzobon et al., 2000). In this species, yellow-anthered biotypes are mostly tetraploid and sexual, while purple-anthered biotypes are penta- and hexaploid apomictics. This is not the case with $P$. ammodes, in which yellow- and purple-anthered plants collected in contiguous populations have the same chromosome number, a feature also documented for distinct individuals of a single accession of $P$. dasypleurum Kunze ex Desv. by Quarín and Caponio (1995). Since P. ammodes is a widespread species in South America (Morrone et al., 2004), it would be interesting to know if additional populations have the same chromosome number.

Paspalum cordatum $(2 \mathrm{n}=20), P$. carinatum $(2 \mathrm{n}=30)$, . trachycoleon $(2 \mathrm{n}=36), P$. bicilium $(2 \mathrm{n}=40)$, P. heterotrichon $(2 \mathrm{n}=40)$, P. lanciflorum $(2 \mathrm{n}=40)$, and P. burmanii $(2 \mathrm{n}$ $=48$ ) are all members of the subgenus Ceresia (Pers.) Rchb. (Denham et al., 2002), which is, however, likely to be a polyphyletic assemblage (Rua and Aliscioni, 2002; Speranza P and Rua $\mathrm{GH}$, unpublished results).

Previous chromosome counts of $\mathrm{n}=10$ and $2 \mathrm{n}=40$ exist for $P$. carinatum (Davidse and Pohl, 1972, 1978), now found in the triploid level.

Paspalum bicilium is narrowly related to P. polyphyllum Nees, where some authors consider it to be a synonym (Denham et al., 2002; Zuloaga and Morrone, 2005). Although 
available counts for P. polyphyllum also showed $2 \mathrm{n}=40$ (Burson, 1997), we prefer to maintain it tentatively as a separate species, based on morphological and ecological evidence. Paspalum polyphyllum and $P$. bicilium, together with $P$. humboldtianum Flüggé and a few other species, are probably unrelated to the rest of the subgenus Ceresia (Rua and Aliscioni, 2002; Speranza $P$ and Rua GH, unpublished results).

Previous counts are available for P. trachycoleon $(\mathrm{n}=20)$ and P. lanciflorum $(\mathrm{n}=18, \mathrm{sub}$ nom. P. contractum) (Davidse and Pohl, 1974), which differ, however, from these reported in this paper. In both cases, regular and unusual chromosome numbers co-exist in the same species, a case also known from another member of the subgenus Ceresia, P. stellatum Humb. and Bonpl. ex Flüggé, in which regular diploids $(2 \mathrm{n}=20)$ occur as well as an unusual polyploid series, comprising $2 \mathrm{n}=32$ and 52 (Honfi et al., 1990; Killeen, 1990). This fact poses a challenging question about a possible hybrid origin of the polyploid cytotypes, perhaps involving quite unrelated species.

Finally, the chromosome number $2 \mathrm{n}=48$ of $P$. burmanii was also unexpected for the genus. It is a poorly known species, endemic to the serpentinic region of Niquelândia, in the State of Goiás (Filgueiras et al., 2001), where several new species of Paspalum were unveiled in recent years (Davidse and Filgueiras, 1993; Filgueiras and Davidse, 1994; Filgueiras, 1995).

The finding of a set of new, unexpected chromosome numbers in Paspalum species suggests that much more collection and cytogenetic characterization are necessary to assess the whole chromosomal and genomic multiplicity present in the genus, which seems to be much more diverse than currently thought to be.

\section{ACKNOWLEDGMENTS}

We acknowledge CNPq, the Brazilian Research Council, for a post-doctoral grant for G.H. Rua, for a scholarship to A.L. Côrtes and for a research productivity grant awarded to J.F.M. Valls.

\section{REFERENCES}

Acuña CA, Martínez EJ and Quarin CL (2005). Sexual diploid and apomictic tetraploid races in Thrasya petrosa (Gramineae). Austr. J. Bot. 53: 479-484.

Allen AC and Valls JFM (1987). Recursos forrageiros nativos do Pantanal Mato-Grossense. EMBRAPA-CENARGEN, Brasília.

Bennett HW (1962). Dallisgrass, Bahiagrass, and Vaseygrass. In: Forages: The Science of Grassland Agriculture (Hughes HD, Heath ME and Metcaffe DS, eds.). Iowa State University Press, Ames, 281-285.

Bennett HW and Brashaw EC (1966). Interspecific hybridization with Paspalum spp. Crop. Sci. 6: 52-54.

Burson BL (1983). Phylogenetic investigations of Paspalum dilatatum and related species. In: Proceedings of International Grassland Congress Westview Press, Lexington, 170-173.

Burson BL (1997). Apomixis and sexuality in some Paspalum species. Crop. Sci. 37: 1347-1351.

Dandin SB and Chennaveeraiah MS (1983). Chromosome number and meiotic behaviour in interpretation of basic chromosome number in the genus Paspalum. J. Cytol. Genet. 18: 26-33.

Daurelio LD, Espinoza F, Quarin CL and Pessino SC (2004). Genetic diversity in sexual diploid and apomictic tetraploid populations of Paspalum notatum situated in sympatry or allopatry. Plant Syst. Evol. 244: 189-199.

Davidse G and Pohl RW (1972). Chromosome numbers, meiotic behavoir, and notes on some grasses from Central America and the West Indies. Can. J. Bot. 50: 1441-1452.

Davidse G and Pohl RW (1974). Chromosome numbers, meiotic behavior, and notes on tropical American grasses (Gramineae). Can. J. Bot. 52: 317-328.

Davidse G and Pohl RW (1978). Chromosome numbers of tropical American grasses (Gramineae): Ann. MO Bot. Gard. 65: 637-649. 
Davidse G and Filgueiras TS (1993). Paspalum longiaristatum (Poaceae: Paniceae), a new serpentine endemic from Goiás, Brazil, and the first awned species in the genus. Novon 3: 129-132.

Denham SS (2005). Revisión sistemática del subgénero Harpostachys de Paspalum (Poaceae: Panicoidae: Paniceae). Ann. MO Bot. Gard. 92: 463-532.

Denham SS, Zuloaga FO and Morrone O (2002). Systematic revision and phylogeny of Paspalum subgenus Ceresia (Poaceae: Panicoideae: Paniceae). Ann. MO Bot. Gard. 89: 337-399.

Espinoza F and Quarín CL (1997). Cytoembryology of Paspalum chaseanum and sexual diploid biotypes of two apomictic Paspalum specie. Austr. J. Bot. 45: 871-877.

Espinoza F and Quarín CL (1998). Relación genómica entre citotipos diploides de paspalum simplex y p. procurrens (poaceae, paniceae). Darwiniana 39: 59-63.

Fernandes MIBM, Barreto IL, Salzano FM and Sacchet AMOF (1974). Cytological and evolutionary relationships in Brazilian forms of Paspalum (Gramineae). Caryologia 27: 455-465.

Filgueiras TS (1992). Gramíneas forrageiras nativas do Distrito Federal, Brasil. Pesq. Agropec. Bras. 27: 1103-1111.

Filgueiras TS (1995). Paspalum niquelandiae (Poaceae: Paniceae), a new species from the serpentine outcrops of central Brazil. Novon 5: 30-33.

Filgueiras TS and Davidse G (1994). Paspalum biaristatum (Poaceae: Paniceae), a new serpentine endemic from Goiás, Brazil, and the second awned species in the genus. Novon 4: 18-22.

Filgueiras TS, Morrone O and Zuloaga FO (2001). Paspalum burmanii (Poaceae: Paniceae), a new species from central Brazil. Novon 11: 36-39.

Giussani LM, Cota-Sánchez JH, Zuloaga FO and Kellogg EA (2001). A molecular phylogeny of the grass subfamily Panicoideae (Poaceae) shows multiple origins of $\mathrm{C}_{4}$ photosynthesis. Am. J. Bot. 88: 1993-2012.

Hojsgaard DH, Honfi AI, Daviña JR and Rua GH (2005). Números cromosómicos de especies sudamericanas de Paspalum L. In: $34^{\circ}$ Congreso Argentino de Genética Trelew. Basic Appl. Genet. 17, Suppl. 119.

Honfi AI, Quarín CL and Valls JFM (1990). Estudios cariológicos en gramineas sudamericanas. Darwiniana 30: 87-94.

Hunziker JH, Zuloaga FO, Morrone O and Escobar A (1998). Estudios cromosómicos en Paniceae sudamericanas (Poaceae: Panicoideae). Darwiniana 35: 29-36.

Killeen TJ (1990). The grasses of Chiquitanía, Santa Cruz, Bolivia. Ann. MO Bot. Gard. 13: 73-77.

Machado ACC, Valls JFM, Peñaloza APS and Santos S (2005). Novos biótipos pentaplóides do grupo Dilatata de Paspalum L. (Gramineae) no Sul do Brasil. Cienc. Rural 35: 56-61.

Morrone O and Zuloaga FO (2003). New species of Paspalum (Poaceae: Panicoideae: Paniceae) from Brazil. Syst. Bot. 28: 307-312.

Morrone O, Denham SS and Zuloaga FO (2004). Revisión taxonómica del género Paspalum, grupo Eriantha (Poaceae, Panicoideae, Paniceae). Ann. MO Bot. Gard. 91: 225-246.

Morrone O, Escobar A and Zuloaga FO (2006). Chromosome studies in American Panicoideae (Poaceae). Ann. MO Bot. Gard. 93: 647-657.

Norrmann GA, Bovo OA and Quarin CL (1994). Postzygotic seed abortion in sexual diploid X apomictic tetraploid intraspecific Paspalum crosses. Austr. J. Bot. 42: 449-456.

Pozzobon MT and Valls JFM (1987). Caracterização citogenética em acessos de germoplasma de espécies brasileiras de Paspalum (Gramineae). In: Anais do Encontro Internacional sobre Melhoramento Genético de Paspalum, Instituto de Zootecnia, Nova Odessa, 73-77.

Pozzobon MT and Valls JFM (1997). Chromosome number in germplasm accessions of Paspalum notatum (Graminea). Braz. J. Genet. 20: 29-34.

Pozzobon MT and Valls JFM (2000). Cytogeography and variation of stomatal size of Paspalum glaucescens (Gramineae; Paniceae) in Southern Brazil. Euphytica 116: 251-256.

Pozzobon MT, Valls JFM and Santos S (2000). Contagens cromossômicas em espécies brasileiras de Paspalum L. (Gramineae). Acta Bot. Bras. 14: 151-162.

Pozzobon MT, Machado ACC, Vaio M, Valls JFM, et al. (2008). Cytogenetic studies in Paspalum (Poaceae) reveal new diploid species and accessions. Cienc. Rural 35: (in press).

Quarín CL (1974). Relaciones cito-taxonomicas entre Paspalum almum Chase y P. hexastachyum Parodi (Gramineae). Bonplandia 3: 115-127.

Quarín CL and Hanna W (1980). Effect of three ploidy levels on meiosis and mode of reproduction in Paspalum hexastachyum. Crop. Sci. 20: 69-75.

Quarín CL and Lombardo EP (1986). Niveles de ploidía y distribución geográfica de Paspalum quadrifarium (Gramineae). Mendeliana 7: 101-107.

Quarín CL and Norrmann GA (1990). Interspecific hybrids between five Paspalum species. Bot. Gaz. 151: 366-369.

Quarín CL and Caponio I (1995). Cytogenetics and reproduction of Paspalum dasypleurum and its hybrids with P. urvillei 
and P. dilatatum ssp. flavescens. Int. J. Plant Sci. 156: 232-235.

Reeder JR (1984). Chromosome number reports LXXXII. Taxon 33: 126-164.

Renvoize SA (1972). Studies in the Gramineae: XXX. Kew Bull. 27: 451-455.

Rua GH and Aliscioni SS (2002). A morphology-based cladistic analysis of Paspalum sect. Pectinata (Poaceae). Syst. Bot. 27: 489-501.

Selva SB (1976). Some preliminary cytological observations on a new basic number in Paspalum convexum (Gramineae). Can. J. Bot. 54: 385-394.

Urbani MH, Quarín CL, Espinoza F, Penteado MIO, et al. (2002). Cytogeography and reproduction of the Paspalum simplex polyploid complex. Plant Syst. Evol. 236: 99-105.

Vaio M, Speranza P, Valls JF, Guerra M, et al. (2005). Localization of the 5S and 45S rDNA sites and cpDNA sequence analysis in species of the Quadrifaria group of Paspalum (Poaceae, Paniceae). Ann. Bot. 96: 191-200.

Zuloaga FO and Morrone O (2005). Revisión de las especies de Paspalum para América del Sur Austral (Argentina, Bolívia, sur de Brasil, Chile, Paraguay y Uruguay). Monograf. Syst. Bot. MO Bot. Gard. 102: 1-297. 